\title{
Lens Aldose Reductase Inhibitory and Free Radical Scavenging Activity of Fractions of Chromolaena odorata (Siam Weed): Potential for Cataract Remediation
}

\author{
Emmanuel O. AJANI ${ }^{1 *}$, Saheed SABIU ${ }^{1,2}$, Fisayo A. BAMISYAE ${ }^{1}$, \\ Nurain O. ISMAILA ${ }^{1}$, Olayinka S. ABDULSALAM ${ }^{1}$ \\ ${ }^{1}$ Kwara State University, Department of Biosciences and Biotechnology, Phytomedicine and Drug Development Laboratory, Malete, PMB 1530, Ilorin, \\ Nigeria; emmanuel.ajani@kwasu.edu.ng( ${ }^{*}$ correspondingauthor) \\ ${ }^{2}$ University of Free State, Faculty of Natural and Agricultural Sciences, South Africa
}

\begin{abstract}
Searching for effective and safe aldose reductase (AR) inhibitor agent is a major thrust area in the mainstream of anti-cataractogenic research. This study was set up to investigate the in vitro aldose reductase inhibitory (ARI) activity of fractions of methanolic extract of Chromolaena odorata leaves, on partially purified AR from goat lens, for potential use in the development of anticataractogenic agent. The phyto-constituents of the leaves were screened in aqueous and methanolic extracts and the free radical scavenging activities of the fractions were evaluated. The kinetics of the enzyme in the presence of fractions of the leaves was then compared. Phenol, flavonoid, alkaloid, saponin, terpenoid, quinones and phlobatannins were detected in both extracts. All the fractions inhibited AR in an uncompetitive manner, showing a reduced V max and Km when compared with glyceraldehyde. ARI activity was found to be the highest with aqueous fraction $\left(\mathrm{IC}_{50}, 0.22 \pm 0.01 \mathrm{mg} / \mathrm{ml}\right)$. All other fractions showed mild to moderate AR inhibition capacity, while it was found to be the lowest within hexane fraction $\left(\mathrm{IC}_{50}, 1.20 \pm 0.10 \mathrm{mg} / \mathrm{ml}\right)$. All the fractions showed free radical scavenging activity and metal chelating activity. The study confirmed the ARI and antioxidant capacity of Chromolaena odorata which may be due to its phenolic constituents, indicating that the plant may serve as a base for the development of anticataract agent.
\end{abstract}

Keywords: aldose reductase, cataract, Chromolaena odorata, free radical, medicinal plant, phytochemical constituents

\section{Introduction}

The use of medicinal plants, plant extracts or plantderived pure chemicals to treat human ailments is an important alternative therapeutic approach (Patwardhan et al., 2004). The medicinal values of plants lie in their component phytochemicals such as alkaloids, tannins, flavonoids and other phenolic compounds, which produce a definite physiological action on the human body. A systematic search for useful bioactivities from medicinal plants is now considered to be a rational approach in nutraceutical and drug research (Akinmoladun et al., 2007). In the past decade, an area of research interest in finding pharmaceutical agents against cataract, regarded as the main cause of blindness worldwide and accounting for $51 \%$ of world blindness (Haque and Gilani, 2005; Rathnakumar et al., 2013), is the search for aldose reductase inhibitors.

Aldose reductase (ALR2; AR; EC 1.1.1.21) is a key enzyme in the polyol pathway that controls the conversion of glucose to sorbitol. The polyol pathway is usually a two- step metabolic process through which glucose is reduced to sorbitol, which is further converted to fructose. The polyol pathway consists of two enzymes. The first enzyme, aldose reductase (AR), reduces glucose to sorbitol with the aid of its co-factor NADPH; the second enzyme, sorbitol dehydrogenase $(\mathrm{SDH})$, with its co-factor $\mathrm{NAD}^{+}$, converts sorbitol to fructose. The AR enzyme is found in almost all mammalian cells, but is richer in organs such as the lens, retina and sciatic nerves, which are affected by diabetic complications.

Increased polyol pathway flux causes accumulation of sorbitol in the lens fiber, which, in turn, causes an increased influx of water and the generation of osmotic stress, thereby leading to cataract formation (Suryanarayana et al., 2004). Thus, reduction of the hyperglycemia-induced polyol pathway flux by AR inhibitors could be a potential therapeutic opening in the treatment and prevention of diabetic complications such as cataract formation. In normal tissue, aldose reductase has low substrate affinity for glucose. However, in diabetes mellitus, the increased availability of glucose in insulin-insensitive tissues such as the lens, nerve and retina leads to the increased formation of sorbitol through the polyol pathway (Gacche and Dhole, 2011; Patel et al., 2012a). 
264

Aldose reductase enzyme and especially its inhibition by aldose reductase inhibitors (ARIs), has been gaining attention over the last years from the pharmaceutical community, as it appears to be a promising pharmacotherapeutic target. Several authors have studied and reported on a number of structurally diverse naturally occurring and synthetic AR inhibitors that have proven to be effective for the prevention of diabetic complications in experimental animals, as well as in clinical trials (Guzmán and Guerrero 2005; Patel et al., 2012b). Although some synthetic aldose reductase inhibitors (ARIs) have been developed as drug candidates, virtually all have not been successful in clinical trials due to adverse pharmacokinetic properties, inadequate efficacy and toxic side effects.

Oxidative stress is another mechanism that is involved in the development of cataract induced by glucose and age related process, due to the formation of superoxide $\left(\mathrm{O}_{2}^{-}\right)$ radicals and $\mathrm{H}_{2} \mathrm{O}_{2}$ which readily react with lens biomolecules (Kyselova et al., 2005). Living cells are constantly exposed to oxidative stress from reactive oxygen species such as $\mathrm{H}_{2} \mathrm{O}_{2}$ and hypochlorous acid $(\mathrm{HClO})$ and the free radicals superoxide $\left(\mathrm{O}_{2}{ }^{-}\right)$and hydroxyl radical ( $\mathrm{OH})$. Endogenous sources include mitochondria, peroxisomes, lipoxygenases, NAPDH oxidase and cytochrome $\mathrm{p} 450$. Mitochondrial superoxide, formed by the incomplete reduction of oxygen in the electron transport chain, is rapidly converted to diffusible $\mathrm{H}_{2} \mathrm{O}_{2}$ by superoxide dismutase and thence to water by catalase or glutathione peroxidase. Nonetheless, lens cells are constantly exposed to $\mathrm{H}_{2} \mathrm{O}_{2}$ and other xenobiotics, and there is a constant need to protect susceptible proteins from oxidation (Michael and Bron, 2011).

Oxygen is a very reactive atom that is capable of becoming part of potentially damaging molecule commonly refers to as "free radicals". Overall, free radicals have been implicated in the pathogenesis of various diseases. Free radicals are capable of attacking the healthy cells of the body, causing them to lose their structure and function. Cell damage caused by free radicals appears to be a major contributor to aging and to degenerative diseases of aging such as cancer, cardiovascular disease, immune system decline, brain dysfunction and cataract (Prasad et al., 2014). The toxic effects of the reactive oxygen species are neutralized in the lens by antioxidants such as ascorbic acid, vitamin E, the glutathione system (GSH peroxidase, GSH reductase), superoxide dismutase and catalase.

Reductions in concentration of glutathione, antioxidant enzymes witch increase with age were the main factors involving the generation of cataract (Manikandan et al., 2009). A compound therefore with antioxidant and free radical scavenging properties may be further justifiably evaluated as a potential approach to the management of cataract.

Chromolaena odorata is a perennial, diffuse and scrambling shrub which grows to 3-7 metres in height when growing in the open. It is commonly called independence weed, Siam weed, bitter bush, or Jack-inthe-bush (Okon and Amalu, 2003). In Nigeria, it is commonly called Awolowo (Yoruba) and "ahihia eliza" or "obiara kara" (Ibo). It is the major weed that is wide spread in Central and West Africa, tropical America, West India, South East Asia and Western part of Nigeria (Phan et al.,
2001; Owoyele et al., 2005; Akinmoladun et al., 2007). The leaves of the plant have been found to be a rich source of flavonoids, of which quercetin, sinensetin, sakuranetin, padmatin, kaempferol, salvagenin were isolated and identified (Ling et al., 2007). It is used as an antibacterial, antiplasmodic, antiprotozoal, antitripanosomal, antifungal, astringent, deutric and hepatropic agent (Phan et al., 2001; Akinmoladun et al., 2007). The crude ethanol extract of the plant had been demonstrated to be a powerful antioxidant that protects fibroblasts and keratinocytes in vitro. The results showed that the phenolic acids present (protocatechuic, p-hydroxybenzoic, p-coumaric, ferulic and vanillic acids) and complex mixtures of lipophilic flavonoid aglycones (flavanones, flavonols, flavones and chalcones) are major and powerful antioxidants that protect cultured skin cells against oxidative damage (Phan et al., 2001).

In spite of its reported antioxidant properties, no reports exist in the literature on the anticataract potential of the plant. This study was thus set up to investigate the aldose reductase inhibitory properties of Chromolaena odorata and the capacity of the plant to scavenge free radicals in vitro.

\section{Materials and Methods}

Quercetin, 2,2-diphenyl-1-picryl hydrazine (DPPH), TCA, Glacial acetic, NADPH, ferrozine, napthylenediamine, dihydrochloride, 1,10phenanthroline, sulfanilic acid, rutin and 2mercaptoethanol were obtained, from Sigma-Aldrich Co. (St. Louis, MO, USA). All other solvents and chemicals used were of analytical grade and were obtained from commercial sources.

Whole plant of Chromolaena odorata was collected from a botanical garden in Egbejila, Ilorin, West local government area of Kwara State in July 2015. The plant was identified at the herbarium of Plant Biology, Kwara State University, Malete, Nigeria, where a voucher specimen (KS/PLH/BB01/042) was deposited. The leaves of the plant were then shade dried for two weeks and then pulversised with a local kitchen blender.

\section{Preparation of extract and fractions}

Exactly $100 \mathrm{~g}$ of the pulverized leaves were macerated in $500 \mathrm{ml}$ of methanol for 7 days. It was then sieved over a muslin cloth first and further with filter paper. The extract was again macerated in another 500 $\mathrm{ml}$ of methanol for another 7 days and then filtered as above. The filtrate was combined and concentrated using a rotary evaporator. The concentrated product was further dried over a water bath at $40{ }^{\circ} \mathrm{C}$. The yield was $15.52 \%$. The dried extract was then fractionated by suspending it in distilled water. Hexane was added to the suspension in ratio of $1: 2$, shook well and allowed to stand for about $15 \mathrm{~min}$ until two layers were formed. The hexane layer was removed and more hexane was added to the aqueous layer. The process was repeated once, and then a colorless hexane layer was seen. The two hexane layers were combined and dried to obtain the hexane fraction. The procedure was repeated with 
the aqueous layer using chloroform and ethyl acetate respectively. Each fraction obtained, including the aqueous fraction, was then collected and dried. The aqueous layer was dried by lyophilization. The weight of the dried fractions were calculated and the sample was then stored in a desiccator for further use.

\section{Isolation and partial purification of goat eye lenses}

Eye ball was removed from goat immediately after sacrifice and stored in ice-cold container. Lenses were removed by lateral incision of the eye, washed with icecold distilled water and kept cold. The lenses were homogenized in 10 volumes of $100 \mathrm{mM}$ ice-cold potassium phosphate buffer, $\mathrm{pH} 6.2$ and centrifuged at $15,000 \mathrm{xg}$ for $30 \mathrm{~min}$ at $4{ }^{\circ} \mathrm{C}$. The resulting supernatant was used as the source of aldose reductase (Suryanarayana et al., 2004; Angel and Ricardo, 2005). Saturated ammonium sulphate (100\%) was added to the supernatant from the homogenate to reach $40 \%$ saturation and then allowed to stand for $15 \mathrm{~min}$ with occasional stirring to ensure the completeness of precipitation. It was then centrifuged and the precipitate was discarded. The same procedure was repeated for the resulting supernatant using $50 \%$ and $75 \%$ ammonium sulphate saturations. The final supernatant was used as the partially purified aldose reductase.

\section{Aldose reductase assay}

Aldose reductase (AR) activity was assayed according to the method described by Hayman and Kinoshita (1965). Enzyme specific activity was calculated as IU/mg protein and this was defined as activity of the enzyme that can produce $1 \mu \mathrm{mol} \mathrm{NADP}^{+}$from $\mathrm{NADPH}$ in $1 \mathrm{~min}$ (Halder et al., 2003).

\section{Inbibition study}

Different concentrations $(0.4-2.8 \mathrm{mg} / \mathrm{ml})$ of the methanolic extract of the leaves and its fractions were prepared in triplicate. Exactly $100 \mu \mathrm{l}$ of concentrations prepared was then added to the assay mixture and incubated for 5-10 min. The reaction was initiated with the addition of NADPH. The absorbance was then read at $340 \mathrm{~nm}$ at the beginning and at the end of $30 \mathrm{~min}$. The percent inhibition (\% ARI) of the extract was then calculated as:

$\%$ ARI $=\Delta$ absorbance (negative control) $-\Delta$ absorbance (fraction)/ $\Delta$ absorbance (negative control) $\times$ 100

The AR activity in the absence of inhibitor was considered as $100 \%$. The concentration of each test sample that gives $50 \%$ inhibition $\left(\mathrm{IC}_{50}\right)$ was then estimated. A negative control was prepared using 5\% DMSO in phosphate buffer ( $\mathrm{pH}$ 6.2).

\section{Determination of kinetic parameters}

The kinetic studies of inhibitory activity against aldose reductase of different fractions were analyzed using the Lineweaver-Burk plot.

\section{Estimation of lens protein concentration}

The protein determination was carried out using the Stoschck (1990) method modified by Lowry et al. (1951).

\section{Assay for free radical scavenging activity}

\section{$D P P H$ radical scavenging assay}

The DPPH (1, 1-diphenyl-2-picryl hydrazyl) radical scavenging method was used to evaluate the antioxidant property of the plant. The antioxidant activity of each sample was expressed in terms of $\mathrm{IC}_{50}$, and this was calculated from the graph after plotting inhibition percentage against extract concentration. The assay was carried out according to the method of Hemalatha et al. (2010). DPPH $(0.1 \mathrm{mM})$ was prepared in methanol and $1.0 \mathrm{ml}$ of its solution was mixed with $1.0 \mathrm{ml}$ of extract/fractions prepared in methanol at different concentrations $(20,40,60,80$ and $100 \mu \mathrm{g} / \mathrm{ml})$. The mixture was shaken well and incubated at room temperature for $30 \mathrm{~min}$ and absorbance was measured at $517 \mathrm{~nm}$ using a UVspectrophotometer. All the experiments were performed in triplicate and the mean was taken. Scavenging activity was calculated from control sample OD using the following equation:

$\mathrm{DPPH}$ - Scavenging capacity $(\%)=\left(\mathrm{A}^{0}\right.$ control $\mathrm{A}^{0}$ sample $/ \mathrm{A}^{0}$ control $) \times 100$

Ascorbic acid was used as positive control. IC $_{50}$ values (concentration of extract/fraction required to reduce $50 \%$ of DPPH radical) were estimated from the graph and compared.

\section{Metal chelating activity}

The method described by Decker and Welch (1990) was used to estimate the metal chelating activity. The extract/fraction $(0.5 \mathrm{~g})$ was mixed with $\mathrm{FeCl}_{3}(2 \mathrm{mM})$ and ferrozine $(0.2 \mathrm{ml})$ in a test tube, and the total volume was diluted with methanol $(2 \mathrm{ml})$. The mixture was vigorously shaken and left standing for $10 \mathrm{~min}$ at room temperature. The absorbance of the solution was measured spectrophotometrically at $562 \mathrm{~nm}$ after the mixture had reached equilibrium. EDTA was used as positive control and the percent inhibition of ferrozine- $\mathrm{Fe}^{2+}$ complex was calculated using the formula below: 100

Percent Scavenging $=\left[\left(\mathrm{A}^{0}\right.\right.$ control $-\mathrm{A}^{0}$ sample $) / \mathrm{A}^{0}$ control $] \times$

Where: $\mathrm{A}^{0}$ control = absorbance of ferrozine $-\mathrm{Fe}^{2+}$ complex; $\mathrm{A}^{0}$ sample $=$ absorbance of test compound.

\section{Hydroxyl radical scavenging activity}

This was carried out according to the method described by Yu et al. (2004). The reaction medium was made up of $60 \mu \mathrm{l}$ of 1 $\mathrm{mM}, \mathrm{Fecl}_{3}, 90 \mathrm{\mu l}$ of $1 \mathrm{mM}$ 1,10-phenanthroline, $2.4 \mathrm{ml}$ of $0.2 \mathrm{M}$ phosphate buffer ( $\mathrm{pH} 7.8), 150 \mu \mathrm{l}$ of $0.17 \mathrm{M} \mathrm{H}_{2} \mathrm{O}_{2}$ and $1.5 \mathrm{ml}$ of various concentration of each fractions/methanol extract. Reaction mixture was kept at room temperature for 5 min incubation and absorbance was then measured at $560 \mathrm{~nm}$ using spectrophotometer. The concentration of the individual sample required to neutralize 50\% hydroxyl radicals were considered as IC 50 values.

\section{Nitric oxide radical scavenging activity}

Method previously described by Garrat (1964) was used for estimating nitric oxide radical scavenging activity. The reaction mixture containing $2 \mathrm{ml}$ of $10 \mathrm{mM}$ sodium nitroprusside, $0.5 \mathrm{ml}$ of phosphate buffer saline $(\mathrm{pH} \mathrm{7.4)}$ and $0.5 \mathrm{ml}$ of plant extract/fraction was incubated at $25^{\circ} \mathrm{C}$ for $2 \mathrm{~h} 30 \mathrm{~min}$. After incubation time, $0.5 \mathrm{ml}$ of reaction mixture was mixed with $1 \mathrm{ml}$ of sulfanilic acid reagent (33\% in $20 \%$ glacial acetic acid) and incubated for $5 \mathrm{~min}$. This was followed by addition of $1 \mathrm{ml}$ napthylenediamine dihydrochloride $(0.1 \% \mathrm{w} / \mathrm{v})$. The mixture 
266

was incubated at room temperature for $30 \mathrm{~min}$. The absorbance was measured at $560 \mathrm{~nm}$ using UV-VIS spectrophotometer. The amount of sample required to scavenge 50\% nitric oxide radicals generated in the control set were calculated as $\mathrm{IC}_{50}$.

\section{Hydrogen peroxide scavenging activity}

The assay method described by Ruch et al. (1989) was used to determine the ability of plant extracts/fraction to scavenge hydrogen peroxide. A solution of hydrogen peroxide (40 mM) was prepared in phosphate buffer ( $\mathrm{pH}$ 7.4). The extract/fractions prepared in distilled water were mixed with 0.6 $\mathrm{ml}$ of hydrogen peroxide solution $(40 \mathrm{mM})$. The absorbance of hydrogen peroxide at $230 \mathrm{~nm}$ was determined after $10 \mathrm{~min}$ against a blank solution containing plant extract/fraction in phosphate buffer without hydrogen peroxide. The absorbance of hydrogen peroxide $(40 \mathrm{mM})$ without plant extract was considered as control (100\%). The concentration of plant extract/fraction required to scavenge $50 \%$ hydrogen peroxide was calculated as $\mathrm{IC}_{50}$.

\section{Reducingpower assay}

This was determined by the previously described method of Oyaizu (1986). The reaction mixture containing $0.75 \mathrm{ml}$ of various concentrations of plant extract/fraction, $0.75 \mathrm{ml}$ of phosphate buffer $(0.2 \mathrm{~N}, \mathrm{pH} 6.6)$ and $0.75 \mathrm{ml}$ of potassium hexacyanoferrate $\left(\mathrm{K}_{3} \mathrm{Fe}(\mathrm{CN})_{6}\right)(1 \% \mathrm{w} / \mathrm{v})$ was incubated at $50^{\circ} \mathrm{C}$ in water bath for $20 \mathrm{~min}$. The reaction was stopped by the addition of $0.75 \mathrm{ml}$ trichloroacetic acid (10\%) and then centrifuged for $10 \mathrm{~min}$ at $800 \mathrm{rpm}$. The supernatant $(1.5 \mathrm{ml})$ of the individual reaction mixture was collected in different clean tubes and was mixed with $1.5 \mathrm{ml}$ of distilled water followed by addition of $0.1 \mathrm{ml}$ ferric chloride $(0.1 \% \mathrm{w} / \mathrm{v})$ and kept for 10 min. The absorbance of reaction mixture was measured at 700 $\mathrm{nm}$ as the reducing power. The absorbance of control was considered as $100 \%$ of $\mathrm{Fe}^{3+}$ ions and $\mathrm{IC}_{50}$ values were determined as the concentration of plant extract/fraction required to inhibit $50 \%$ reduction of $\mathrm{Fe}^{3+}$ ions.

\section{Phytochemicalscreening}

The methanolic and aqueous extracts of the plant were subjected to different chemical tests for the detection of different phytoconstituents using standard procedures (Harborne, 1973; Trease and Evans, 1989; Sofowora, 1993).

\section{Results}

Shown in Table 1 and Table 2 respectively are the results of the yield of the crude methanolic extract and its sub-fractions and the results of the phytochemical constituents of the aqueous and methanolic extract. The yield of the methanolic extract was $7.75 \%$. Fractionation of the methanolic extract yielded $5.25 \%$ aqueous fraction, $11.31 \%$ ethyl acetate fraction, 3.47 hexane fraction and $39.87 \%$ chloroform fraction. The result of the preliminary

Table 1. Yield of $C$. odorata extract/ fraction

\begin{tabular}{lc}
\hline Extract/ Fraction & Yield \\
\hline Methanol & 7.75 \\
Aqueous & 5.25 \\
Ethylacetate & 11.31 \\
Hexane & 3.47 \\
Chloroform & 39.82 \\
\hline
\end{tabular}

Table 2. Phytochemicals of $C$. odorata

\begin{tabular}{lcc}
\hline $\begin{array}{l}\text { Phytochemical } \\
\text { constituents }\end{array}$ & Aqueous extract & Methanolic extract \\
\hline Phenols & + & + \\
Phlobatannins & - & - \\
Tannins & + & - \\
Flavonoids & + & + \\
Saponins & + & + \\
Steroids & + & - \\
Alkaloids & + & + \\
Anthocyanins & - & - \\
Cardiac glycosides & + & + \\
Terpenoids & + & + \\
Quinones & + & + \\
\hline Note: + denotes detected and - denotes not detected &
\end{tabular}

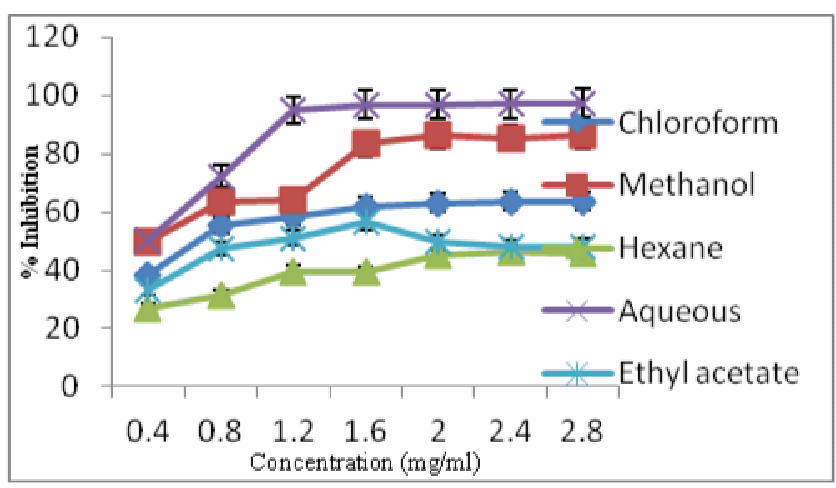

Fig. 1. Inhibitory effect of $C$. odorata fractions on the specific aldose reductase activity

phytochemical screening revealed the presence of alkaloids, glycosides, saponins, phenols and flavonoids in both extracts. Tannin and steroids were detected only in the aqueous extract, while phlobatannins were not detected in any of the extract.

The variation in percentage inhibition of $\mathrm{AR}$ with increasing concentration of the extract/fraction of $C$. odorata is shown in Fig. 1, while the result of $\mathrm{IC}_{50}$ is shown in Table 3. The lowest $\mathrm{IC}_{50}$ of $0.22 \pm 0.01 \mathrm{mg} / \mathrm{ml}$ was obtained with aqueous fraction. The estimated $\mathrm{IC}_{50}$ was however not significantly different $(\mathrm{p}>0.05)$ from $\mathrm{IC}_{50}$ of $0.30 \pm 0.03 \mathrm{mg} / \mathrm{ml}$ and $0.33 \pm 0.03$ obtained with chloroform fraction and methanolic extract respectively. The highest $\mathrm{IC}_{50}$ was obtained with hexane fraction (1.20 $\pm 0.01 \mathrm{mg} / \mathrm{ml})$ and this was significantly higher $(\mathrm{p}<0.05)$ than $\mathrm{IC}_{50}$ value of $0.60 \pm 0.03 \mathrm{mg} / \mathrm{ml}$ obtained with ethylacetate fraction.

Shown in Fig. 2 is the lineweaver-Burk plot, while Table 4 summarizes the results of aldose reductase kinetics after the enzyme was incubated with different fractions of C. odorata. Data obtained in the study indicates that all the fractions showed uncompetitive inhibition. The aldose

Table 3. $\mathrm{IC}_{50}(\mathrm{mg} / \mathrm{ml})$ of fractions of $C$. odorata

\begin{tabular}{lc}
\hline Fraction & $\mathrm{IC}_{50}(\mathrm{mg} / \mathrm{ml})$ \\
\hline Chloroform & $0.30 \pm 0.03^{\mathrm{a}}$ \\
Methanol & $0.33 \pm 0.01^{\mathrm{a}}$ \\
Ethyl acetate & $0.60 \pm 0.03^{\mathrm{b}}$ \\
Aqueous & $0.22 \pm 0.01^{\mathrm{a}}$ \\
Hexane & $1.20 \pm 0.10^{\mathrm{c}}$ \\
\hline
\end{tabular}


Table 4. Kinetics parameters of aldose reductase enzyme in the presence of different fractions of $C$. odorata leaves

\begin{tabular}{|c|c|c|}
\hline Extract/Fraction & $\begin{array}{c}\mathrm{Vmax} \\
(\mu \mathrm{m} \text { NADPH oxidised/hr/100 mg protein })\end{array}$ & $\mathrm{Km} \mathrm{X} 10^{-3} \mathrm{mM}$ \\
\hline DL-glyceraldehyde & $0.830 \pm 0.012^{\mathrm{a}}$ & $5.683 \pm 0.002^{\mathrm{a}}$ \\
\hline DL- glyceraldehyde + methanol & $0.035 \pm 0.011^{\mathrm{b}}$ & $2.501 \pm 0.061^{b}$ \\
\hline DL- glyceraldehyde + chloroform & $0.066 \pm 0.001^{\mathrm{c}}$ & $0.915 \pm 0.031^{\mathrm{c}}$ \\
\hline DL- glyceraldehyde + hexane & $0.041 \pm 0.003^{\mathrm{d}}$ & $0.803 \pm 0.021^{c}$ \\
\hline DL- glyceraldehyde + ethylacetate & $0.029 \pm 0.002^{\mathrm{e}}$ & $2.527 \pm 0.002^{\mathrm{b}}$ \\
\hline DL- glyceraldehyde + aqueous & $0.026 \pm 0.014^{\mathrm{e}}$ & $3.380 \pm 0.053^{\mathrm{d}}$ \\
\hline
\end{tabular}

Table 5. Free radical scavenging activity of extract and fractions of $C$. odorata leaves

\begin{tabular}{|c|c|c|c|c|c|c|}
\hline Extract/Fractions & $\begin{array}{c}\text { DPPH IC } 50 \\
(\mathrm{mg} / \mathrm{ml})\end{array}$ & $\begin{array}{c}\text { Metal chelating } \\
\text { activity (\%) }\end{array}$ & $\begin{array}{l}\mathrm{OH} \mathrm{IC}_{50} \\
(\mathrm{mg} / \mathrm{ml})\end{array}$ & $\begin{array}{c}\mathrm{H}_{2} \mathrm{O}_{2} \mathrm{IC}_{50} \\
(\mathrm{mg} / \mathrm{ml})\end{array}$ & $\begin{array}{l}\text { Reducing power } \\
\mathrm{IC}_{50}(\mathrm{mg} / \mathrm{ml})\end{array}$ & $\begin{array}{l}\mathrm{NO} \mathrm{IC}_{50} \\
(\mathrm{mg} / \mathrm{ml})\end{array}$ \\
\hline Methanol & $0.051 \pm 0.002$ & 82.8 & $0.715 \pm 0.100$ & $0.436 \pm 0.021$ & $0.095 \pm 0.022$ & $0.651 \pm 0.022$ \\
\hline Aqueous & $0.046 \pm 0.005$ & 92.5 & $0.513 \pm 0.001$ & $0.486 \pm 0.009$ & $0.083 \pm 0.007$ & $0.562 \pm 0.013$ \\
\hline Ethylacetate & $0.085 \pm 0.018$ & 30.0 & $0.965 \pm 0.019$ & $0.765 \pm 0.032$ & $0.164 \pm 0.042$ & $0.568 \pm 0.019$ \\
\hline Chloroform & $0.062 \pm 0.004$ & 44.1 & $1.672 \pm 0.015$ & $0.889 \pm 0.016$ & $0.416 \pm 0.015$ & $0.871 \pm 0.011$ \\
\hline Hexane & $0.095 . \pm 0.011$ & 21.1 & $1.652 \pm 0.102$ & $0.968 \pm 0.023$ & $0.516 \pm 0.012$ & $0.912 \pm 0.056$ \\
\hline
\end{tabular}

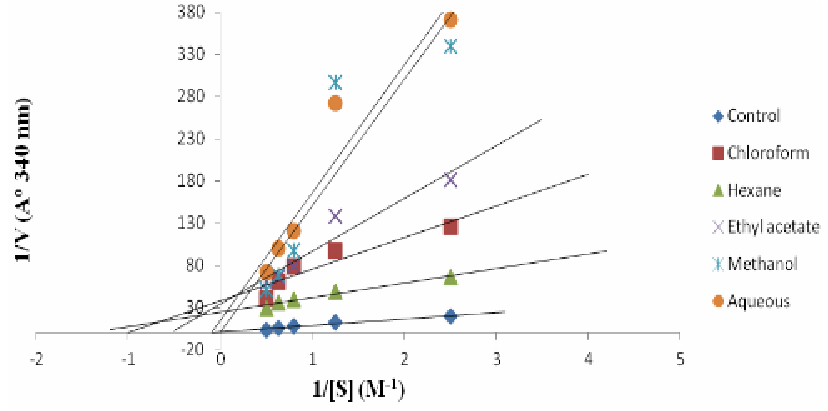

Fig. 2. Effect of different fractions of $C$. odorata on lineweaverBurk plot of aldose reductase activity

reductase kinetics (Vmax and $\mathrm{Km}$ ) obtained for all the fractions were significantly $(\mathrm{p}<0.05)$ lower than that of the glyceraldehyde (control). The Vmax of $0.006 \pm 0.001$ $\mu \mathrm{m} \mathrm{NADPH}$ oxidised/hr/100 mg protein obtained with chloroform fraction was the lowest while the $\mathrm{Km}$ of 0.803 \pm 0.021 obtained with hexane fraction was the lowest. The Vmax of $0.029 \pm 0.002 \mu \mathrm{m} \mathrm{NADPH}$ oxidised/hr/100 mg protein obtained with ethylacetate fraction was not significantly different from $0.026 \pm 0.002 \mu \mathrm{m}$ NADPH oxidised/hr/100 mg protein obtained with aqueous fraction and $0.035 \pm 0.011 \mu \mathrm{m}$ NADPHoxidised/hr/100 $\mathrm{mg}$ protein obtained with methanol fraction. Among all the fractions, the highest $\mathrm{Km}$ of $\mathrm{AR}$ was obtained when incubated with aqueous fraction $\left(3.380 \pm 0.053 \mathrm{mM}^{-1}\right)$. The Km of AR obtained with methanol and ethylacetate fractions were not significantly different from each other $\left(2.501 \pm 0.061 \mathrm{mM}^{-1}\right.$ and $2.527 \pm 0.002 \mathrm{mM}^{-1}$ respectively).

The result of the free radical scavenging activities of the fractions of C. odorata is presented in Table 5. Aqueous fraction of $C$. odorata showed the highest DPPH scavenging activity with $\mathrm{IC}_{50}$, of $\left.0.046 \pm 0.002 \mathrm{mg} / \mathrm{ml}\right)$ followed by the methanolic extract $\left(\mathrm{IC}_{50}, 0.051 \pm 0.002\right.$ $\mathrm{mg} / \mathrm{ml}$ ) while hexane fraction was observed to show the least DPPH scavenging activity ( $\mathrm{IC}_{50}, 0.095 \pm 0.011$ $\mathrm{mg} / \mathrm{ml}$ ). The metal chelating capacity of the fractions followed a similar pattern with the aqueous fraction, showing the highest metal chelating capacity of $92.5 \%$, closely followed by methanol extract (82.8\%). The least metal chelating activity of $21.1 \%$ was shown by the hexane fraction. Ethylacetate and chloroform fraction showed a mild metal chelating capacity of $30 \%$ and $44.1 \%$ respectively. Whereas the aqueous fraction showed a potent $\mathrm{OH}$ scavenging activity with $\mathrm{IC}_{50}$ of $0.513 \pm 0.001$ $\mathrm{mg} / \mathrm{ml}$, other plant fractions exhibited mild to moderate $\mathrm{OH}$ radical scavenging potential in the $\mathrm{IC}_{50}$ range of 0.715 \pm 0.100 to $1.672 \pm 0.015 \mathrm{mg} / \mathrm{ml}$. The highest $\mathrm{H}_{2} \mathrm{O}_{2}$ scavenging activity $\left(\mathrm{IC}_{50}, 0.430 \pm 0.021 \mathrm{mg} / \mathrm{ml}\right)$ was shown by the methanol extract, but the activity was not significantly $(\mathrm{p}>0.05)$ different from that of the aqueous fraction (IC $50,0.486 \pm 0.009 \mathrm{mg} / \mathrm{ml}$ ). All other fractions showed ineffective $\mathrm{H}_{2} \mathrm{O}_{2}$ scavenging activities with $\mathrm{IC}_{50}$ values ranging from $0.765 \pm 0.032 \mathrm{mg} / \mathrm{ml}$ (ethylacetate) to $0.968 \pm 0.023 \mathrm{mg} / \mathrm{ml}$ (hexane fraction). Aqueous fraction also showed the strongest reducing power $\left(\mathrm{IC}_{50}, 0.083 \pm\right.$ 0.007); however, the observed IC 50 with this fraction was not significantly different from that of methanol fraction $\left(\mathrm{IC}_{50}, 0.095 \pm 0.022\right)$. The least reducing power was shown by the hexane fraction $\left(\mathrm{IC}_{50}, 0.516 \pm 0.012\right)$. All the fractions showed a mild NO scavenging activity with $\mathrm{IC}_{50}$ ranging from $0.562 \pm 0.013$ (aqueous fraction) to $0.912 \pm 0056$ (hexane fraction).

\section{Discussion}

Preliminary qualitative test according to Savithramma et al. (2011) is useful in the detection of bioactive principles and subsequently may lead to drug discovery and development. The phytochemical screening and qualitative estimation of the plants studied showed the presence of tannins, flavonoids, saponin, steroids, alkaloids, cardiac glycosides and terpenoids in both extracts of $C$. odorata leaves investigated. This thus justifies the acclaimed medicinal properties of the plant. Reports have shown that medicinal plants contain some organic compounds which produce definite physiological action on the human body. These bioactive substances include tannins, alkaloids, carbohydrates, terpenoids, steroids and flavonoids (Mann, 1978, Edoga et al., 2005). They are of great importance to the health of individuals and communities. Phenolics are especially common in leaves, flowering tissues and woody parts, such as stems 
268

and barks. Reports have implicated phenolic compounds including flavonoids as having health beneficial properties. This medicinal property has been attributed to inhibition of certain enzymes particularly, aldose reductase and xanthine oxidase, and also their antioxidant activity (Balasundram et al., 2006; Urszula et al., 2015). Phenolics have been known to possess a capacity to scavenge free radicals. This antioxidant activity of phenolics is principally due to their redox properties, which allow them to act as reducing agents and hydrogen donors. Studies have shown that they play an important preventive role in the development of cancer, heart diseases and ageing related diseases (Anjali and Shetal, 2013).

Aqueous and methanol extracts were used for screening of phytochemicals in order to evaluate the best solvent for the extraction of bioactive principles of the plant. Report from the study indicates that except for tannins (which were only detected in the aqueous extract), steroids (which were detected only in the methanolic extract), phlobatannins and anthocyanins (which were not detected in any of the extracts), all other phytochemicals screened for were detected in both extracts of the plants. In the literature, different solvent combinations have been used to extract antioxidants from plant materials such as fruits, vegetables and other foodstuffs. Reports indicated that the most widely used solvents for extracting phenolic compounds are water, ethanol, methanol, acetone and their water mixtures (Bunea, 2010; Rababah et al., 2012). The present study is in agreement with these studies and thus showed that both methanol and water were effective in extracting the bioactive principle of $C$. odorata leaves. A study by Boeing et al. (2014) noted that among pure solvents, methanol was the most efficient solvent for extraction of antioxidant compounds, followed by water, ethanol and acetone. This observation was supported by another report of Urszula et al. (2015). When the yields of the fractions were compared, results from the present study indicated that the highest yield was obtained with chloroform, while the lowest yield was obtained with hexane. The study suggests that although antioxidants principle may be better extracted by polar solvents (Boeinget al., 2014; Urszula et al., 2015) generally, more phytochemicals are extracted in less polar solvents, but not in non-polar solvents.

The inhibitory effects of plant phytochemicals, including polyphenols (which are currently regarded as natural antioxidants) against carbohydrate hydrolyzing enzymes and their antioxidant activities are important for human health (Viswanatha et al., 2010; Girija et al., 2011). Results from this study indicate that different fractions of C. odorata leaves showed significant aldose reductase inhibitory activity. This inhibitory effect was maximum with aqueous fraction, but least with hexane fraction. All other fractions showed moderate to weak AR inhibitory activity. Significant research efforts have been going on all over the world on the investigation of naturally-occurring biomarkers responsible for inhibiting the enzyme aldose reductase. In an attempt to develop potent, safe and new ARI agents from natural sources, many plant materials and isolated phytoconstituents have been tested for ARI activity in both in vivo and in vitro models (Jung et al.,
2008; Ajani et al., 2009; Patel et al., 2012a; Patel et al., 2012b). In a review that evaluated some indigenous plants reported to have potent ARI activities and their anticataract potentials against galactose-induced biochemical changes in rat lens organ culture, Patel $e t$ al. (2012b) reported that Ocimum sanctum was the most effective ARI in vitro with $\mathrm{IC}_{50}$ value of $20 \mu \mathrm{g} / \mathrm{ml}$. Data from this study indicated that the $\mathrm{IC}_{50}$ of fractions of $C$. odorata ranged from 0.22 (aqueous fraction) to 1.20 $\mathrm{mg} / \mathrm{ml}$ (hexane fraction). The lowest AR inhibitory activity observed with hexane fraction support the fact that the solvent is least efficacious in extracting the antioxidant principles of the plant. This may be due to the low efficiency of solvation with the solvent, since hexane molecules are only proton acceptors while methanol and water are also proton donors.

The detection of phenols and flavonoids as reported in this study suggest that the aldose reductase inhibitory action of C. odorata may be due to these phytoconstituents. Flavonoids are commonly ingested from fruits and vegetables in the diet; although they have no nutritive value, they are capable of exerting various pharmacological activities, including antioxidative, superoxide- scavenging and aldose reductase inhibitory activity (Patel et al., 2012a). Several flavonoids, such as quercitrin, guaijaverin and desmanthin have been tested and proven for their inhibitory activity against aldose reductase (Kato et al., 2009). Previous study has reported that phenolic compounds are one of the most widely occurring groups of phytochemicals and are of considerable physiological and morphological importance in plants (Balasundram et al., 2006; Urszula et al., 2015). There are many reports that this group of phytochemicals possesses biological activity. The antioxidant activity of polyphenols is due to their ability to scavenge free radicals, donate hydrogen atoms or electron, or chelate metal cations (Amarowicz et al., 2004; Balasundram et al., 2006; Urszula et al., 2015). Zhang et al. (2013) reported that the presence of electron-donating and electron-withdrawing substituents in the ring structure of phenolics, as well as the number and arrangement of the hydroxyl groups, determines their antioxidant potential.

The kinetic study was performed for the entire fraction in order to elucidate the mode of inhibition of the aldose reductase enzyme by the fraction/extract. Effect of different fractions on rat lens aldose reductase activity in Lineweaver-Burk plot using DLglyceraldehyde as a substrate was made between 1 /velocity vs $1 / \mathrm{DL}$ glyceraldehyde. The results of the kinetic studies suggest that the aldose reductase inhibitory compounds present in C. odorata extract/fractions can interact and inhibit lens aldose reductase enzyme in an uncompetitive manner, appearing to interact with the enzyme at a site independent of either substrate or enzyme. An uncompetitive inhibitor binds exclusively to the enzymesubstrate complex, yielding an inactive enzyme-substrateinhibitor complex. The effect of an uncompetitive inhibitor is to decrease both Vmax and $\mathrm{Km}$. $\mathrm{Km}$ is a measure of substrate affinity for the enzyme. A lower Km corresponds to a higher affinity. The presence of an uncompetitive inhibitor actually increases the affinity of 
the enzyme for the substrate. Since the inhibitor binds the E-S complex, the inhibitor decreases the concentration of the E-S (Copeland, 2005). Despite their rarity in drug discovery programs, uncompetitive inhibitors could have dramatic physiological consequences. As the inhibitor decreases the enzyme activity, there is an increase in the local concentration of substrate. Without a mechanism to clear the buildup of substrate, the potency of the uncompetitive inhibitor will increase. From the value of Vmax and $\mathrm{Km}$ it was concluded that aqueous fraction showed the maximum inhibitory potential whereas hexane fraction showed the least inhibition in the entire tested fraction.

Free radicals can initiate the oxidation of bio molecules, such as protein, lipid, amino acids and DNA, which will lead to cell injury and can induce numerous diseases. Cataract formation has been attributed to oxidative stress triggered by reactive oxygen species (ROS), which include superoxide anion $\left(\mathrm{O}_{2}^{-}\right)$, nitric oxide (NO), hydrogen peroxide $\left(\mathrm{H}_{2} \mathrm{O}_{2}\right)$ and hydroxyl radicals $\left(\mathrm{OH}^{-}\right)$. $\mathrm{O}_{2}^{-}$in itself is not highly toxic, but it may react with other molecules such as NO, yielding more reactive compounds (Ramar et al., 2010). An excess of NO, produced by inducible nitric oxide synthases (iNOS) upon stimulation, is thought to cause cell injury by nitrosative stress and this may occur in certain diseases. In the eye, NO contributes to allergic conjunctivitis (Meijer et al., 1996), glaucoma (Schneemann et al., 2002), diabetic retinopathy (Tsai et al., 2003) and cataract (Ito et al., 2001). OH is another highly reactive free radical known to contribute to lens crystalline modification (Fu et al., 1998). The plant's fractions investigated in the present study were found to possess significant free radical scavenging activity. A cursory look at the $\mathrm{IC}_{50}$ values presented in Table 5 clearly showed that the aqueous fraction and the methanol extract were more efficacious than all other fractions in scavenging $\mathrm{DPPH}, \mathrm{OH}, \mathrm{H}_{2} \mathrm{O}_{2}, \mathrm{O}_{2}$ and $\mathrm{NO}$ radicals. The study thus suggest that the free radical scavenging capacities of the fractions have a strong relationship with the solvent employed, mainly due to the different antioxidant potential of compounds with different polarities. Reducing power is associated with antioxidant activity and may serve as a significant reflection of the antioxidant activity. Compounds with reducing power indicate that they are electron donors and can reduce the oxidized intermediates of lipid peroxidation processes, so that they can act as primary and secondary antioxidants (Anjali and Sheetal, 2013). Results from this study indicate that the aqueous and methanol fraction, when compared with other fractions investigated, had a better reducing power and metal chelating capacity.

\section{Conclusions}

This study indicates that the leaf extract of $C$. odorata contained phenolic compounds including flavonoid that might have accounted for the strong free radical scavenging activity against $\mathrm{DPPH}, \mathrm{H}_{2} \mathrm{O}_{2}, \mathrm{NO}, \mathrm{O}_{2}^{-}, \mathrm{OH}$ radicals and also reducing power and metal chelating activity. The findings of the current investigation further suggests that $C$. odorata leaves could be a potential source of natural antioxidant that possess aldose reductase inhibitory activity and that aqueous fraction and methanolic extract of $C$. odorata is more efficacious as an AR inhibitor and free radical scavengers than all other fraction studied. Further investigation on the isolation and characterization of the antioxidant constituents and in vivo study to confirmed these observed in vitro activity is however required.

\section{References}

Ajani EO, Salako AA, Sharlie PD, Akinleye WA, Adeoye AO, Salau BA, Adebawo OO (2009). Chemopreventive and remediation effect of Hydrocotyl bonariensis Comm. Ex Lam (Apiaceae) leave extract in galactose-induced cataract. Journal of Ethnopharmacology 123:134-142.

Akinmoladun AC, Ibukun EC, Dan-Ologe IA (2007). Phytochemical constituents and antioxidant properties of extracts from the leaves of Chromolaena odorata. Scientific Research and Essays 2:191-194.

Amarowicz R, Pegg RB, Rahimi-Moghaddam P, Barl B, Weil JA (2004). Free-radical scavenging capacity and antioxidant activity of selected plant species from the Canadian prairies. Food Chemistry 84:551-562.

Angel G, Ricardo OG (2005). Inhibition of aldose reductase by herbs extracts and natural substances and their role in prevention of cataracts. Revista Cubana de Plantas Medicinales 10:10-15.

Anjali S, Sheetal S (2013). Phytochemical analysis and free radical scavenging potential of herbal and medicinal plant extracts. Journal of Pharmacognosy and Phytochemistry 2(4):22-29.

Balasundram N, Sundram K, Samman S (2006). Phenolic compounds in plants and agri-industrial by-products: antioxidant activity, occurrence, and potential uses. Food Chemistry 99:191203.

Bunea CI, Pop N, Babeş AC, Matea C, Dulf FV, Bunea A (2012). Carotenoids, total polyphenols and antioxidant activity of grapes (Vitis vinifera) cultivated in organic and conventional systems. Chemistry Central Journal 6:66-74.

Copeland RA (2005). Evaluation of enzyme inhibitors in drug discovery: A guide for medicinal chemists and pharmacologists. Wiley, New York pp 243-147.

Decker EA, Welch B (1990). Role of ferritin as a lipid oxidation catalyst in muscle food. Journal of Agricultural and Food Chemistry 38:674-677.

Edoga HO, Okwu DE, Mbaebie BO (2005). Phytochemicals constituents of some Nigerian medicinal plants. African Journal of Biotechnology 4(7):685-688.

Fu S, Dean RT, Southan M, Truscott RJW (1998). The hydroxyl radical in lens nuclear cataractogenesis. The Journal of Biological Chemistry 273:28603-28609.

Gacche RN, Dhole NA (2011). Profile of aldose reductase inhibition, anti-cataract and free radical scavenging activity of selected medicinal plants: An attempt to standardize the botanicals for amelioration of diabetes complications. Food and Chemical Toxicology 49:1806-1813.

Garrat DC (1964). The quantitative analysis of drugs, vol 3. Chapman and Hall Ltd, Japan pp 456-458. 
270

Girija K, Lakshman K, Chandrika U, Ghosh SS, Divya T (2011). Antidiabetic and anti-cholesterolemic activity of methanol extracts of three species of Amaranthus. Asian Pacific Journal of Tropical Biomedicine 1:133-138.

Guzmán A, Guerrero RO (2005). Inhibition of aldose reductase by herbs extracts and natural substances and their role in prevention of cataracts. Revista Cubana de Plantas Medicinales 10:3-4.

Halder N, Joshi S, Gupta SK (2003). Lens aldose reductase inhibiting potential of some indigenous plants. Journal of Ethnopharmacology 86:113-116.

Haque SE, Gilani KM (2005). Effect of Ambroxol spirulina and Vitamin $E$ in naphthalene induced cataract in female rats. Indian Journal of Physiology and Pharmacology 49:57-64.

Harborne JB (1973). Phytochemical methods. Chapman and Hall Ltd, London pp 49-188.

Hayman S, Kinoshita Jin H (1965). Isolation and properties of lens aldose reductase. The Journal of Biological Chemistry 240:877882.

Hemalatha S, Lalitha P, Arulpriya P (2010). Antioxidant activities of the extracts of the aerial roots of Pothos aurea (Linden ex Andre). Der Pharma Chemica 2(6):84-89.

Ito $Y$, Nabekura T, Takeda M, Nakao M, Terao M, Hori R, Tomohiro M (2001). Nitric oxide participates in cataract development in selenite-treated rats. Current Eye Research 22:215-220.

Boeing JS, Barizão ÉO, e Silva BC, Montanher PF, de Cinque Almeida V, Visentainer JV (2014). Evaluation of solvent effect on the extraction of phenolic compounds and antioxidant capacities from the berries: application of principal component analysis. Chemistry Central Journal 8:48-53.

Jung HA, Yoon NY, Kang SS, Kim YS, Choi JS (2008). Inhibitory activities of prenylated flavonoids from Sophora flavescens against aldose reductase and generation of advanced glycation endproducts. Journal of Pharmacy and Pharmacology 60(9):1227-1236.

Kato A, Yasuko H, Goto H, Hollinshead J, Nash RJ, Adachi I (2009). Inhibitory effect of rhetsinine isolated from Evodia rutaecarpa on aldose reductase activity. Phytomedicine 16(2-3):258-261.

Kyselova SJ, Garcia J, Gajdosikova A, Stefek M (2005). Temporal relationship between lens protein oxidation and cataract development in streptozocin-induced diabetic rats. Physiological Research 54:49-56.

Ling SK, Md Pisar M, Man AS (2007). Platelet-activating factor (PAF) receptor binding antagonist activity of the methanol extracts and isolated flavonoids from Chromolaena odorata (L.) King and Robinson. Biological and Pharmaceutical Bulletin 30(6):1150-1152.

Lowry OH, Rosebrough NJ, Farr AL, Randall NJ (1951). Protein measurement with folin phenol reagent. Journal of Biological Chemistry 193:265-275.

Mann J (1978). Secondary metabolism. Oxford University Press, London pp 154.

Manikandan R, Thiagarajan R, Beulaja S, Chindhu S, Mariammal K, Sudhandiran G, Arumugam M (2009). Anti-cataractogenic effect of curcumin and aminoguanidine against selenium-induced oxidative stress in the eye lens of Wistar rat pups: an in vitro study using isolated lens. Chemico-Biological Interactions 181:202-209.

Meijer F, Van Delft JL, Garrelds IM, Van Haeringen NJ, Kijlstra A (1996). Nitric oxide plays a role as a mediator of conjuctival edema in experimental allergic conjunctivitis. Experimental Eye Research 62:359-365.

Michael R, Bron AJ (2011). The ageing lens and cataract: a model of normal and pathological ageing. Philosophical Transactions of the Royal Society 366: 1278-1292.

Okon PB, Amalu UC (2003). Using weed to fight weed. Leisa Magazine. Retrieved 2015 Nov 27 from http://www.metafro.be/leisa/2003/194-21.pdf.

Owoyele VB, Adediji JO, Soladoye AO (2005). Anti-inflammatory activity of aqueous leaf extract of Chromolaena odorata. Inflammopharmacology 13(5-6):479-484.

Oyaizu M (1986). Studies on products of browning reactions: antioxidant activities of products of browning reaction prepared from glucose amine. Japanese Journal of Nutrition 44:307-315.

Patel DK, Kumar R, Sairam K, Hemalatha S (2012a). Pharmacologically tested aldose reductase inhibitors isolated from plant sources - A concise report. Chinese Journal of Natural Medicines 10(5):0388-0392.

Patel DK, Kumar R, Kumar M, Sairam K, Hemalatha S (2012b). Evaluation of in vitro aldose reductase inhibitory potential of different fraction of Hybanthus enneaspermus Linn F. Muell. Asian Pacific Journal of Tropical Biomedicine 18:134-139.

Patwardhan B, Vaidya ADB, Chorghade M (2004). Ayurveda and natural products drug discovery. Current Science-Bangalore 86(6):789-799.

Phan TTL, Wang P, See RJ, Grayer SY, Chan T, Lee ST (2001). Phenolic compounds of Chromolaena odorata protect cultured skin cells from oxidative damage: implication for cutaneous wound healing. Biological and Pharmaceutical Bulletin 24:1373137.

Prasad MP, Ashwin Rajkumar R (2014). In vitro antioxidant assay of citrus species using DPPH method. Indian Journal of Advances in Plant Research 14:01-03.

Rababah TM, Banat F, Rababah A, Ereifej K, Yang W (2010). Optimization of extraction conditions of total phenolics, antioxidant activities, and anthocyanin of oregano, thyme, terebinth, and pomegranate. Journal of Food Science 75:626-632.

Ramar M, Raman T, Sivagnanam B, Ganapasam S, Munuswamy A (2010). Curcumin prevents free radical-mediated cataractogenesis through modulations in lens calcium. Free Radical Biology \& Medicine 48:483-492.

Rathnakumar K, Jaikumar S, Duraisami R, Sengottuvelu S (2013). Anticataract activity of Ervatamia coronaria leaf extract on chemically induced cataractogenesis in rats. Global Journal of Research on Medicinal Plants \& Indigenous Medicine 2(4):213218.

Ruch RJ, Cheng SJ, KlaunigJE (1989). Prevention of cytotoxicity and inhibition of intracellular communication by antioxidant catechins isolated from Chinese green tea. Journal of 
Carcinogenesis 10:1003-1008.

Savithramma N, Linga Rao M, Suhrulatha D (2011). Screening of medicinal plants for secondary metabolites. Middle-East Journal of Scientific Research 8(3):579-584.

Schneemann A, Dijkstra BG, van den Berg TJ, Kamphuis W, Hoyng PF (2002). Nitric oxide/guanylate cyclase pathways and flow in anterior segment perfusion. Graefe's Archive for Clinical and Experimental Ophthalmology 240:936-941.

Sofowora A (1993). Medicinal plants and traditional medicine in Africa. Spectrum Books Ltd, Ibadan, Nigeria pp 191-289.

Suryanarayana P, Anil Kumar P, Megha S, Mark P, Reddy G (2004). Inhibition of aldose reductase by tannoid principles of Emblica officianalis: Implications for prevention of sugar cataract. Molecular Vision 10:148-154.

Trease GE, Evans WC (1989). Pharmacognosy. Bailliere Tindall, London pp 45-50.

Tsai DC, Chiou SH, Lee FL, Chou CK, Chen SJ, Peng CH, Kuo YH, Chen CF, Ho LL, Hsu WM (2003). Possible involvement of nitric oxide in the progression of diabetic retinopathy. Ophthalmologica 217:342-346.
Urszula Z, Sylwia M, Małgorzata N, Michał S (2015). The effect of different solvents and number of extraction steps on the polyphenol content and antioxidant capacity of basil leaves (Ocimum basilicum L.) extracts. Saudi Journal of Biological Sciences 23(5):628-633.

Viswanatha GLS, Vaidya SK, Ramesh C, Krishnadas N, Rangappa S (2010). Antioxidant and antimutagenic activities of bark extract of Terminalia arjuna. Asian Pacific Journal of Tropical Medicine 3:965-970.

Yu W, Zhao Y, Shu B (2004). The radical scavenging activities of Radix puerariae isoflavonoids: a chemiluminescence study. Food Chemistry 86:525-529.

Zhang HY, Sun YM, Wang XL (2003). Substituent effects on O-H bond dissociation enthalpies and ionization potentials of catechols: a DFT study and its implications in the rational design of phenolic antioxidants and elucidation of structure-activity relationships for flavonoid antioxidants. Chemistry - A European Journal 9(2):502-508. 